\title{
Thoracic surgery after the COVID-19 pandemic: keep going at full speed
}

For the $7^{\text {th }}$ consecutive year, the Editorial Board of the Fournal of Thoracic Disease $(\mathcal{F T D})$ presents a special issue collecting invited lectures presented during the European Society of Thoracic Surgeons (ESTS) Annual Conference.

During the past 2 years the COVID-19 pandemic hugely impacted on the organization of all medical conferences and educational programs, and the international restrictions prohibited the organization of on-site medical conferences, including the ESTS Annual Meeting.

In October 2020 a virtual 2-day ESTS meeting was organized, when invited lectures and abstracts were presented. The delegates' attendance and the participation of sponsors was beyond any expectation, and once again ESTS demonstrated to represent a strong, well-represented and top-quality Thoracic Surgical Society in the world.

In order to maintain the tradition of the European Perspective of Thoracic Surgery, we are happy that $7 T D$ accepted, even in this difficult period, to published relevant and focused articles from the October conference.

It was an honor and a privilege for the two of us to be considered as co-editors of this issue. After a careful search, we selected, reviewed and approved four papers which, in our opinion, cover a range of interesting areas of interest for the thoracic surgical community.

The topics include the followings: (I) the importance of learning after investigating and debriefing adverse events, which is becoming a crucial aspect of our daily clinical practice; (II) the fundamental role of training programs for robotic-assisted thoracic surgery (RATS) and for RATS lobectomy, in a period where robotic surgical programs are increasing worldwide; (III) a very interesting paper from a large-volume robotic thoracic surgical institution about a simulation model for team training during major crisis during RATS procedures; (IV) the optimal timing for chest wall stabilization of rib fractures after major trauma.

As you can see, the selection was intended to cover a wide range of topics, from medico-legal issues to education to management of particularly challenging clinical situations. It is our understanding that the selected topics in the present collection should be regarded as essential for the education of a complete, modern and competent thoracic surgeon.

We would like to express a special thanks to all the authors and to the editorial staff of $7 T D$ who, despite the current complicated and exceptional worldwide situation, were able to produce a top-quality collective volume, a precious tool for the education of the young generations of thoracic surgeons worldwide.

It is our hope that we will soon get back to a new normality, where people can reconvene in person at the ESTS Annual Conference, sharing experiences, physically interacting at the Conferences and at the associated social events.

We wish all the readers of this volume a healthy 2021, with the hope and the promise to meet together in The Hague, The Netherlands in June 2021.

\section{Acknowledgments}

Funding: None.

\section{Footnote}

Provenance and Peer Review: This article was commissioned by the editorial office, Fournal of Thoracic Disease for the series "European Perspectives in Thoracic Surgery (2020) - the Seven Edition". The article did not undergo external peer review.

Conflicts of Interest: Both authors have completed the ICMJE uniform disclosure form (available at https://dx.doi.org/10.21037/ jtd-21-1171). The series "European Perspectives in Thoracic Surgery (2020) - the Seven Edition" was commissioned by the editorial office without any funding sponsorship. $\mathrm{AB}$ and $\mathrm{ER}$ served as the unpaid Guest Editors of the series. $\mathrm{AB}$ serves as an unpaid editorial board member of Fournal of Thoracic Disease from Dec 2019 to Nov 2021. AB reports consulting and 
honoraria for the following: Medtronic, Ethicon, Astra Zeneca, Bd, Roche. The authors have no other conflicts of interest to declare.

Ethical Statement: The authors are accountable for all aspects of the work in ensuring that questions related to the accuracy or integrity of any part of the work are appropriately investigated and resolved.

Open Access Statement: This is an Open Access article distributed in accordance with the Creative Commons AttributionNonCommercial-NoDerivs 4.0 International License (CC BY-NC-ND 4.0), which permits the non-commercial replication and distribution of the article with the strict proviso that no changes or edits are made and the original work is properly cited (including links to both the formal publication through the relevant DOI and the license). See: https://creativecommons.org/ licenses/by-nc-nd/4.0/.

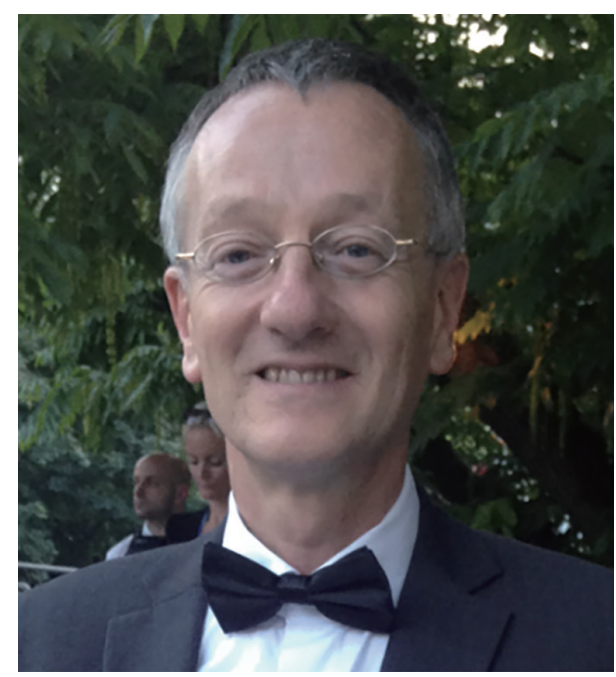

Enrico Ruffini

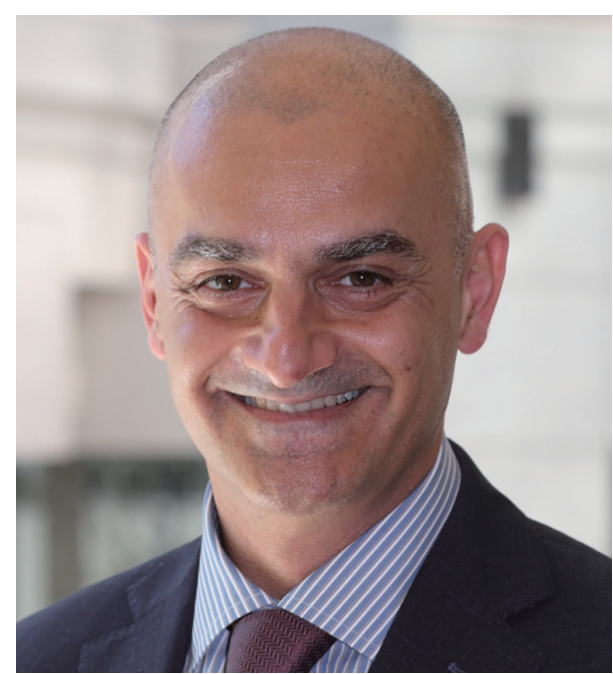

Alessandro Brunelli

Enrico Ruffini, MD

Department of Thoracic Surgery, University of Torino, Torino, Italy. (Email: enrico.ruffini@unito.it)

Alessandro Brunelli, MD

Department of Thoracic Surgery, St. Fames's University Hospital, Leeds, UK. (Email: brunellialex@gmail.com) Submitted Jul 16, 2021. Accepted for publication Jul 29, 2021.

doi: $10.21037 /$ jtd-21-1171

View this article at: https://dx.doi.org/10.21037/jtd-21-1171

Cite this article as: Ruffini E, Brunelli A. Thoracic surgery after the COVID-19 pandemic: keep going at full speed. J Thorac Dis 2021;13(Suppl 1):S1-S2. doi: 10.21037/jtd-21-1171 